\title{
Nutrient intake of WIC participants ages 6--28 months compared to dietary reference intakes
}

\author{
Kara L. Turner \\ West Virginia University
}

Follow this and additional works at: https://researchrepository.wvu.edu/etd

\section{Recommended Citation}

Turner, Kara L., "Nutrient intake of WIC participants ages 6--28 months compared to dietary reference intakes" (2004). Graduate Theses, Dissertations, and Problem Reports. 2000.

https://researchrepository.wvu.edu/etd/2000

This Thesis is protected by copyright and/or related rights. It has been brought to you by the The Research Repository @ WVU with permission from the rights-holder(s). You are free to use this Thesis in any way that is permitted by the copyright and related rights legislation that applies to your use. For other uses you must obtain permission from the rights-holder(s) directly, unless additional rights are indicated by a Creative Commons license in the record and/ or on the work itself. This Thesis has been accepted for inclusion in WVU Graduate Theses, Dissertations, and Problem Reports collection by an authorized administrator of The Research Repository @ WVU. For more information, please contact researchrepository@mail.wvu.edu. 


\title{
NUTRIENT INTAKE OF WIC PARTICIPANTS AGES 6-28 MONTHS COMPARED TO DIETARY REFERENCE INTAKES
}

\author{
Kara L. Turner
}

\begin{abstract}
Thesis submitted to the College of Agriculture, Forestry, and Consumer Sciences

At West Virginia University In partial fulfillment of the requirements

For the degree of
\end{abstract}

\author{
Master of Science \\ In \\ Family and Consumer Sciences \\ Cindy Fitch, Ph.D., Chair \\ Betty Forbes, MA, RD, LD \\ Erron Huey, Ph.D \\ Division of Family and Consumer Sciences
}

\author{
Morgantown, West Virginia \\ 2004
}

Keywords: toddler, infant, nutrient, vitamin, mineral, inadequacy, DRI Copyright 2004 Kara L. Turner 


\section{ABSTRACT \\ Nutrient Intake Of WIC Participants Ages 6-28 Months Compared To Dietary Reference Intakes}

\section{Kara Turner}

Consuming the proper amounts of nutrients is important in each stage of life. Infants and toddlers especially need to consume the right amounts of nutrients for optimal growth and development. This study examined the nutrient intake and dietary variety of infants and toddlers ages 6-28 months enrolled in the Special Supplemental Nutrition Program for Women, Infants, and Children. The data were collected from 87 participants in ten rural West Virginia counties. The two age groups analyzed were 6-11.9 months and 12-28 months.

Two multi-pass 24-hour dietary recalls were obtained from caregivers of the child. These recalls were compared to the current Dietary Reference Intakes (DRIs), to determine what nutrients were low for the two age groups. Analyses included descriptive statistics, Chi Square, Fisher's exact test, correlations, and Z-scores were determined through statistical analysis.

Children were not meeting needs for vitamin D, manganese, vitamin E, selenium, and pantothenic acid. The DRI for manganese and vitamin D were not being meet in either age group. Eighty-seven percent and $74.5 \%$ of children were not meeting manganese needs for groups 1 and 2 respectively. A relationship between dietary variety and selenium, vitamin B-6, magnesium, and riboflavin adequacy was found $(\mathrm{P}<0.05)$. 


\section{ACKNOWLEDGEMENTS}

I would like to extend my thanks to my committee members. Dr. Cindy Fitch, committee chair, guided me and helped me throughout this process. Thank you for being understanding and patient. I want to thank Mrs. Betty Forbes and Dr. Erron Huey, also committee members, whom assisted me in multiple ways to enable me to complete this project. Finally, I want to thank George Seidel for his extensive help with my statistics. Without everyone's assistance, this thesis would not have come together. 
TABLE OF CONTENTS

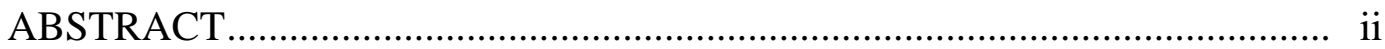

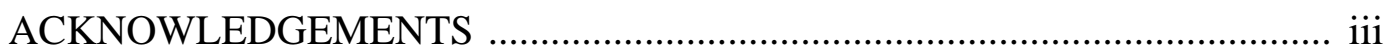

LIST OF TABLES .................................................................................... vi

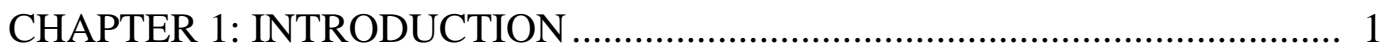

CHAPTER 2: LITERATURE REVIEW ……………….............................. 3

Dietary Reference Intakes............................................................................

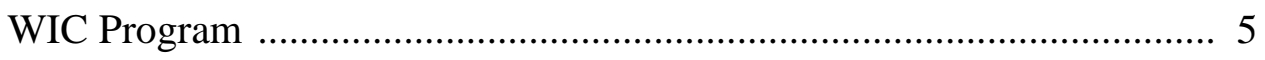

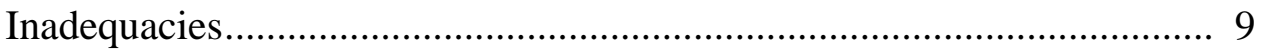

Typical content of infant's and toddler's diets .........................................16

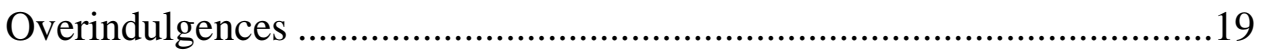

Summary of problematic nutrients...........................................................22

Statement of the problem ...........................................................................24

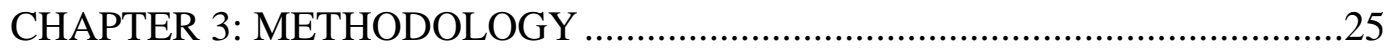

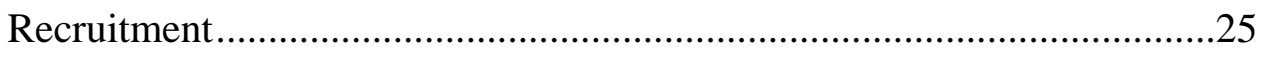

Appointment with research assistant ........................................................26

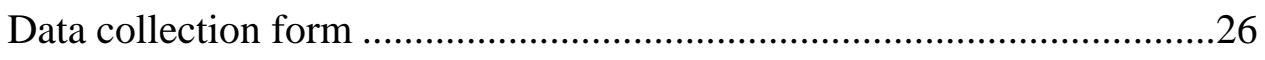

Diet history form ...................................................................................26

Dietary assessment- Multiple Pass 24-hour recall .....................................26

Analysis of diet ....................................................................................2

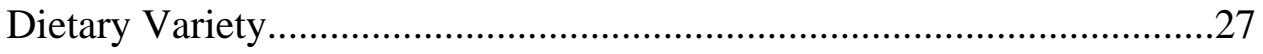

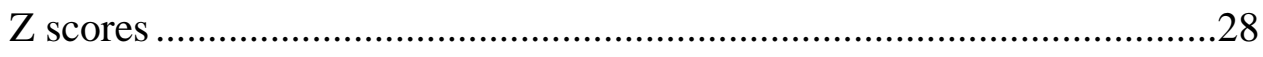

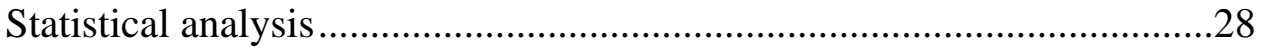




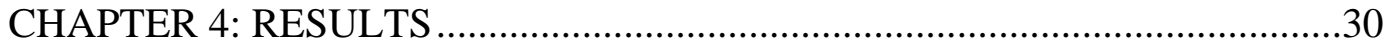

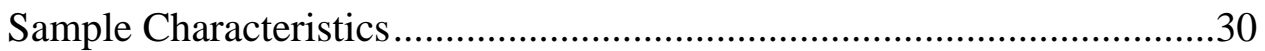

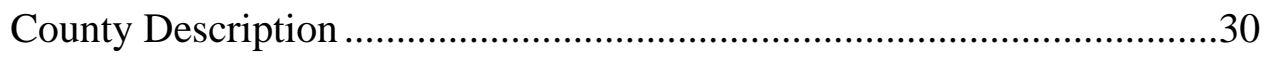

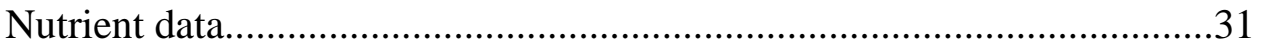

Dietary Variety and Adequacy.........................................................33

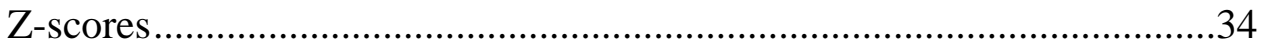

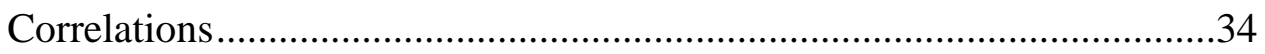

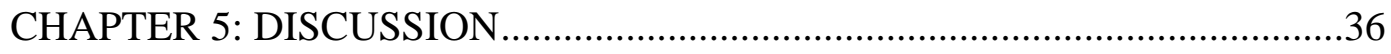

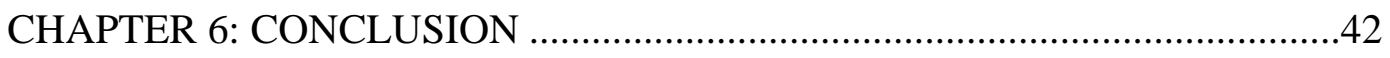

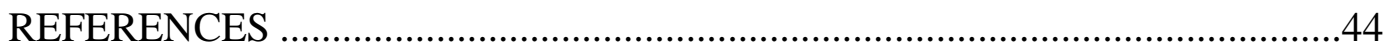

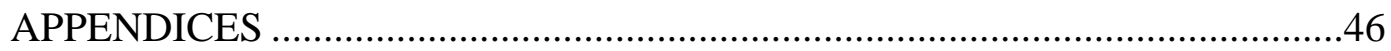

APPENDIX A: WIC Income Eligibility Guidelines ............................47

APPENDIX B: Consent Form \& Study Flyer .....................................49

APPENDIX C: Data Collection Form ..................................................53

APPENDIX D: Diet History Form ....................................................56

APPENDIX E: 24-Hour Recall Script ................................................58

APPENDIX F: Individual Intake Form .............................................62

APPENDIX G: WV Counties Map of Participating WIC Agencies .........65 
TABLE 1: Dietary Reference Intakes.............................................................

TABLE 2: Study Sample for Ponza et al ...........................................................

TABLE 3: Low nutrients for Skinner et al study..................................................14

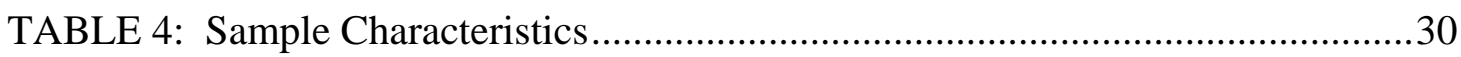

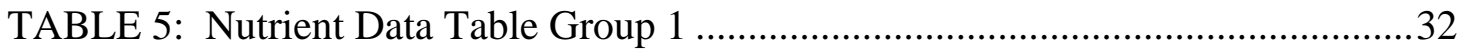

TABLE 6: Nutrient Data Table Group 2 .............................................................32

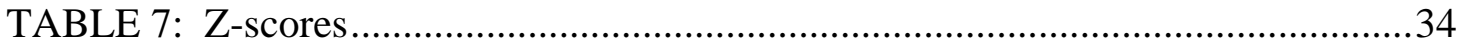

TABLE 8: Correlations between number of meat servings and total energy intake ...35 


\section{Chapter 1}

\section{Introduction}

The eating habits and practices of children are ever changing. Children today eat differently than the children of twenty years ago. One reason for this is that fast and junk food are readily available today, thus there are more opportunities for children to eat poorly. However, there is a great need for children's diets to be of high nutritional value, because a good nutritional base is needed at the beginning of life. Additionally, good eating habits are established at a young age and are typically carried throughout life. Therefore, it is important to help children with their food choices to ensure a healthy diet.

The Special Supplemental Nutrition Program for Women, Infants, and Children (WIC) is one program that can help support good food habits. WIC is a program that identifies pregnant or postpartum women, infants, and children under the age of five years who have a nutritional risk. WIC is available to this group of people who meet certain financial guidelines. WIC provides infant formula, milk, eggs, cheese, peanut butter or beans, and certain cereals to those who qualify. WIC helps those who are of a lower socioeconomic status to get the best nutrition for their children as they can.

This study will examine a population of children that are in the WIC program. One major goal of this study is to describe the nutrients that are consumed by this population. The objectives of this study are as follows:

- To describe the dietary intake of the infants and toddlers

- To determine if there is a relationship between Weight for Height (WHZ) and Weight for Age (WAZ) Z-scores and energy and grams of protein 
- To describe WHZ and WAZ-scores of this population, which are based on national standards

- To determine if there is a relationship between dietary variety and adequacy of the nutrients analyzed

- To compare nutrient intakes to current Dietary Reference Intakes (DRIs)

Thus, this study seeks to answer several questions. First,are children and infants in this range of age groups meeting their DRIs for each nutrient? Next, which vitamins and mineral needs are they meeting and how close are they to meeting those that they are below? Finally, is there a difference between the six to 11.9 months age group and the twelve to twenty four month olds in how close to the DRIs they are meeting? The objective of this study is to gain further insight to the average diet of these young children. 


\section{Chapter 2}

\section{Literature Review}

Good nutritional food habits are important to establish early in a child's life. A child's requirements for vitamins and minerals are equally important when compared to those of adolescents, adults, and the elderly. Proper nutrition is a vital part of infant growth and development.

\section{Dietary Reference Intakes (DRI)}

DRIs are a tool that can be used to assess the quality of an individual's diet (Food and Nurtition Board, Institute of Medicine, 1997). DRIs include Estimated Average Requirement (EAR), Recommended Dietary Allowance (RDA), Adequate Intake (AI), and Tolerable Upper Intake Level (UL). EARs are estimates of the values to meet the requirements for $50 \%$ of healthy individuals in a specific group therefore, EARs are an estimated median. They surpass the needs of half of the group and do not meet the needs of the other half. RDA's are the average daily dietary intake that is adequate to meet nutrient requirements for $97-98 \%$ of people in a specific group. Alternately, RDAs are two standard deviations above the EAR. Next, AIs are established when there is not enough evidence to determine an EAR. Levels for AIs are based on an experiment or observation averages of nutrient intakes by a group of people. Thus, AIs are set at a level to meet the needs of almost all people in a certain group. Finally, ULs are the upper level of any nutrient intake daily that is safe to consume without adverse health problems. Listed below are the DRIs for the different nutrients that will be assessed at for this project. 
TABLE 1

\section{Dietary Reference Intake (DRI) Table}

\begin{tabular}{|c|c|c|c|c|}
\hline Nutrient & 0-6 month AI & $\begin{array}{l}\text { 7-12 month AI } \\
\text { or EAR }\end{array}$ & 1-3 years EAR & $1-3$ years AI \\
\hline Calcium & 210mg/day & 270mg/day & 500mg/day & \\
\hline Phosphorus & 100mg/day & 275mg/day & 380mg/day & \\
\hline Magnesium & 30mg/day & 75mg/day & 65mg/day & \\
\hline Vitamin D & $5 \mu g /$ day & $5 \mu \mathrm{g} / \mathrm{day}$ & & $5 \mu \mathrm{g} /$ day \\
\hline Fluoride & $0.01 \mathrm{mg} /$ day & $0.5 \mathrm{mg} /$ day & & $0.7 \mathrm{mg} /$ day \\
\hline Thiamin & $0.2 \mathrm{mg} /$ day & $0.3 \mathrm{mg} /$ day & $0.4 \mathrm{mg} /$ day & \\
\hline Riboflavin & $0.3 \mathrm{mg} / \mathrm{day}$ & $0.4 \mathrm{mg} /$ day & $0.4 \mathrm{mg} /$ day & \\
\hline Niacin & $2 \mathrm{mg} /$ day & 4mg/day & 5mg/day & \\
\hline B-6 & $0.1 \mathrm{mg} / \mathrm{day}$ & $0.3 \mathrm{mg} /$ day & $0.4 \mathrm{mg} /$ day & \\
\hline Folate & $65 \mu \mathrm{g} /$ day & $80 \mu \mathrm{g} /$ day & $120 \mu \mathrm{g} / \mathrm{day}$ & \\
\hline B-12 & $0.4 \mu \mathrm{g} / \mathrm{day}$ & $0.5 \mu \mathrm{g} / \mathrm{day}$ & $0.7 \mu \mathrm{g} / \mathrm{day}$ & \\
\hline Pantothenic acid & $1.7 \mathrm{mg} /$ day & $1.8 \mathrm{mg} /$ day & & 2mg/day \\
\hline Vitamin A & $400 \mu \mathrm{g} / \mathrm{day}$ & $500 \mu \mathrm{g} / \mathrm{day}$ & $210 \mu \mathrm{g} / \mathrm{day}$ & \\
\hline Copper & $200 \mu \mathrm{g} / \mathrm{day}$ & $220 \mu \mathrm{g} / \mathrm{day}$ & $260 \mu \mathrm{g} / \mathrm{day}$ & \\
\hline Iron & $0.27 \mathrm{mg} / \mathrm{day}$ & 6.9mg/day (EAR) & 3.0mg/day & \\
\hline Manganese & $0.003 \mathrm{mg} / \mathrm{day}$ & $0.6 \mathrm{mg} /$ day & & $1.2 \mathrm{mg} /$ day \\
\hline Zinc & $2 \mathrm{mg} / \mathrm{day}$ & 2.5mg/day (EAR) & $2.5 \mathrm{mg} / \mathrm{day}$ & \\
\hline Vitamin C & 40mg/day & 50mg/day & 13mg/day & \\
\hline Vitamin E & 4mg/day & $5 \mathrm{mg} /$ day & $5 \mathrm{mg} /$ day & \\
\hline Selenium & $15 \mu \mathrm{g} / \mathrm{day}$ & $20 \mu \mathrm{g} /$ day & $17 \mu \mathrm{g} /$ day & \\
\hline
\end{tabular}

( Based on information from the Food and Nutrition Board, 1997, 1998, 2000, and 2001) 


\section{WIC Program}

The Special Supplemental Nutrition Program for Women, Infants, and Children (WIC) is a program that helps lower income families with children under age five years, pregnant, and lactating women supplement their diets with nutrient rich foods. The WIC program was designed to help meet specific nutrient needs including iron, vitamin A, and vitamin C.

The importance of the WIC program is shown in a study done by Rose et al (1998) in which examination of if the WIC Program and Food Stamp Program help with increasing preschooler's nutrient intakes. This study was done using the Continuing Survey of Food Intake by Individuals (CSFII). The participants in this study were children from ages one year to five years that were either eligible for the WIC Program, Food Stamp Program, both, or neither. Children that were breast-fed on the survey days were excluded from the study. The Continuing Survey of Food Intake by Individuals (CSFII) was used to collect three consecutive days of the children's diets. Day one used a 24-hour recall and days two and three consisted of their food records. The household respondent gave the diet information for the children. Nutrients in the foods were calculated by determining the weight of the food eaten and the nutritive value of that particular food. Many nutrients were calculated and they included: energy, protein, vitamins A, E, C, B-6, thiamin riboflavin, niacin, folate, calcium, phosphorus, iron, and zinc. Also, calories from fat, cholesterol, and energy from saturated fat were calculated. This study showed that food stamp participation resulted in an increase of both iron and zinc compared to eligible nonparticipants. For iron and zinc in the WIC group, the averages showed an increase of $1.7 \mathrm{mg} /$ day in iron and $1.1 \mathrm{mg} / \mathrm{d}$ in zinc. Also in the 
WIC group, results showed that ten out of the fifteen nutrients had increased intake by the children compared to eligible nonparticipants. This positive effect of WIC may be because of the certain food vouchers given to participants for highly nutritious foods. This study showed that both WIC and Food Stamp Programs are beneficial to increasing the nutrient intake of the preschoolers.

Examination of foods consumed by WIC participants is important in determining if the program can help increase nutrient intakes. Ponza et al in 2004 examined the nutrient intakes, feeding patterns, and foods eaten in infants and children who were taking part in the WIC program. The researchers were assessing four different questions: 1) What are the characteristics of infants and toddlers in the WIC program? 2) What are the feeding patterns and transitions of infants and toddlers in WIC? 3) What are the usual nutrient intakes of WIC participants, and do they have nutritionally sound diets? 4) What foods do infants and toddlers in WIC consume?

For this study, the researchers used data from the Feeding Infants and Toddlers Study (FITS). FITS provide information on infants and toddlers food and nutrient intakes. FITS is made up of three separate interviews from March 2002 to July 2002, which were all done by telephone. A household interview, 24-hour dietary recall, and a second day 24-hour dietary recall for a random subsample were all conducted. The FITS sample was comprised of participants from the New Parent Database by Experian that consisted of 3,022 infants and toddlers 4-24 months of age.

Nutrition Data System for Research from the University of Minnesota Nutrition Coordinating Center was used to collect the 24-hour dietary recalls. For infants that were only breast fed, $780 \mathrm{ml}$ of breast milk per day was the assumed consumption. If the infant 
was receiving formula and breast milk, the amount of formula consumed was subtracted from 780ml per day to approximate the amount of breast milk consumed.

Three subgroups were examined for this study. The groups were infants 4-6 months, 7-11 months, and toddlers 12-24 months of age that were in the WIC program and those who were non-participants. The table below shows the different groups.

Table 2: Study sample for Ponza et al, (2004)

\begin{tabular}{|l|l|l|}
\hline & Participants & Non-Participants \\
\hline 4-6 months & 265 & 567 \\
\hline 7-11 months & 351 & 808 \\
\hline $12-24$ months & 205 & 791 \\
\hline
\end{tabular}

Infant and toddler feeding patterns were analyzed by collecting data from the parents of the children. Data collected included breastfeeding status, cow's milk introduction, and when specific foods were added to the diet. Nutrient analysis was done by calculating mean usual intake of energy and the following nutrients: calcium, iron, protein, vitamin A, and vitamin C. To analyze foods consumed percentages of foods eaten from different food groups was calculated.

The results showed that 95\% of WIC infants aged 4-6 months consumed formula and that $96 \%$ of the 7-11 months age group did the same. Seventy percent of infants 4-6 months and 95\% of the 7-11 month group ate cereal or pureed foods. WIC participants were also less likely to have been breast fed than non-participants were. 
Energy intake for both the participants and non-participants exceeded estimated energy requirements. Vitamin A intake exceeded the UL for toddlers 12-24 months of age. For the participants $40 \%$ exceeded the UL and $34 \%$ for the non-participants. Nonparticipants had 10\% prevalence for iron inadequacy. Inadequacy in this case means the percentage of infants with usual intakes less than the estimated average requirement (EAR).

Food choices varied a little between participants and non-participants. Nonparticipants were more likely to consume a pre-sweetened cereal (25\%) compared to participants. Similar amounts of vegetables were eaten between the two groups. Consumption of fruits in the WIC group ages 4-6 months was higher than it was in the non-participants, although the older ages non-participants consumed more fruits than the WIC participants. Non-baby food meat was consumed in higher amounts by the participants than the non-participants in the 4-6 month age group. The amount of sweets and desserts eaten increased with age. Finally, WIC participants were more likely to drink a $100 \%$ juice than were non-participants.

This study supplied helpful data on the nutrient intakes, choices from the food groups, and feeding patterns for the WIC population. This study, by using FITS data showed a comparison between WIC participants and non-participants. There were not many noticeable differences in the two populations, but there were a few that were notable. The higher incidence of iron inadequacy, consumption of more sugary cereals, and less consumption of $100 \%$ fruit juice in non-participants are a few results that show the importance of the WIC program and some of the effects it can have on the population that it was designed for. 


\section{Inadequacies}

The studies examined in this section deal with nutrients in which the participants in each study had problems meeting their needs. An inadequacy for this section means that the participants were not meeting the recommended values for the nutrient being studied. These studies are important because they give us an idea of nutrients that children may have a difficult time consuming adequate amounts.

In 2000, Picciano et al assessed the diet quality of infants and babies and the transition of this group into a more adult style type of diet (Picciano et al. 2000). Fiftyfive children aged 12 to 18 months, from the State College Pennsylvania area participated in this study. It was a longitudinal study, designed to assess infant nutrition and growth over a six month time period. The participants were identified through birth announcements in newspapers. The researcher mailed information to the families about the study and then the families were contacted by telephone. All the infants had to meet several categories for qualification: 1) Birth weight greater than 2500g, 2) no congenital abnormalities, 3) no jaundice that was treated with phototherapy, 4) no hospitalization or supplementation with micronutrients during six months before the study, 5) no chronic illness, and 6) anthropometric reference values for birth weight, length, and head circumference within the $10^{\text {th }}$ to $90^{\text {th }}$ percentiles.

To assess the nutrient intake of the participants, three-day dietary records were collected each month throughout the study. In most cases, the mothers recorded the infant's intakes. For those infants that were in day care, extensive instruction was provided on how to record the dietary intakes. The Diet Assessment Center at Pennsylvania State University, Department of Nutrition was used to analyze the dietary 
data for the infants. The intakes of nutrients were calculated as an average amount for each day and compared to the RDAs, 1989. Also, during home visits anthropometric measures of growth were measured on the subjects. Repeated-measures analysis of variance statistics were used on the dietary data.

The results indicated that the children were within normal ranges in anthropometric measures. Most of the subjects were characterized as lean. In regards to energy intake, the kcals consumed seemed to increase from 12 to 16 months and then leveled off through 18 months of age at about 1050 kcals. Energy yielding nutrients like carbohydrates, fat, and protein also increased over time, although a large part of the subjects' diets were not providing adequate levels of fat. At twelve months of age $22 \%$ of the children were consuming less than $30 \%$ of calories from fat in their diets and at 18 months 33\% were also eating less than $30 \%$ of calories as fat. Three key nutrients vitamin A, vitamin E, and iron decreased overtime. Vitamin A did decrease overtime, but the levels of vitamin A were still above the recommended value. Vitamin $\mathrm{E}$ and iron decreases were below the reference standards. Formula and breast milk provided an average of $17 \%$ of the vitamin $\mathrm{E}$ and $51 \%$ of the iron at twelve months of age, but as the child decreased its breast milk or formula consumption, so did these values At this age when much of the diet is breast milk or formula based, it is an important component of the diet because formula and breast milk contain most of the nutrients and infant would need. Grains provided $14 \%$ and 33\% of the total intake of vitamin $\mathrm{E}$ and $68 \%$ and $76 \%$ of the total intake of iron at ages 12 and 18 months respectively. Mean zinc levels did increase over time, but they were still below the recommended levels. As the study progressed, the average folate increased from $60 \%$ to $100 \%$ of the recommended value. 
This study showed how important the transition of diet for infants from milk or formula based diet to one with more solid and adult foods. Vitamin E and iron seemed to be a problematic area for the infants in this study. Both of these nutrients decreased as the diet changed from formula or breast milk based diet to a toddler type diet, to be below recommended values. Although Vitamin A also decreased, it remained above the recommended levels. Another nutrient lacking in the infants' diets was zinc. It did increase over time, but it was still well below the levels that the subjects should have been receiving. Energy increases were associated with normal growth for the participants. Fat intake levels also posed a concern for the infants. Many of the participants at both 12 and 18 months were getting less than 30\% of their kilocalories from fat. Fat should not be restricted until the children are two years old and then it should be done gradually. The diet of young children is vital and transition states for their diets are very essential. Adequate nutrients are crucial for the importance of good health and nutrition. When changing types of diets for infants, proper precautions may need to be made to make sure their diets are adequate.

To ensure proper growth and development, receiving adequate amounts of nutrients is imperative. Nolan et al (2002) looked at energy and the intakes of five nutrients of infants from low-income families. The nutrients analyzed were: protein, calcium, iron, zinc, and vitamin D. The participants were recruited from obstetrical visits. The sample group had to be eligible for WIC programs. Three hundred sixteen pregnant women enrolled in this program. A parent of each subject (infant) was to be interviewed at 3, 6, 9, 12, 18, and 24 months of age. The mother at each of the visits did a 24-hour dietary recall for the infant's previous days diet. Models and standard 
measures were given to the mothers to help them in giving an accurate accounting of the foods eaten. Anthropometric measurements were taken at each visit.

Of the 316 enrolled for the program, 200 completed at least one visit and 147 completed the 24-month study with a minimum of three interviews. Eight hundred eighty seven dietary recalls were used and analyzed using Nutritionist IV software. Nineteen mothers reported breastfeeding, so due to lack of food intake they were omitted. Mean nutrient and energy intake were calculated at each of the visits and compared to RDAs.

The demographics of the mothers showed that 51\% had not completed high school, 73\% were unmarried, and the mean age was 22 years. The majority of the mothers were black (56\%), 41\% were white, and 4\% were of Hispanic origin.

The anthropometric data showed by negative Z-scores that males were lighter and shorter than the US growth standards at most ages. At all ages other than 6 and 9months, females exceeded the US reference length and weight Z-scores.

The average intake of energy and nutrients either met or exceeded the RDAs at almost every age. One exception was that the mean zinc intake did not meet the RDA at 12 and 18 months. At these ages, more than two-thirds did not receive adequate zinc. The lowest level was at age 12 months, when zinc intake was $67 \%$ of the RDA. Another exception was the vitamin D intake. Vitamin D levels were lower than the RDA at 9, 12, 18, and 24 months. At 9 months the average of vitamin D intake was $94 \%$ of the RDA, but this level dropped to less than $75 \%$ of the RDA at the last visit. As the infants got older, the more prevalent the decrease in intake of vitamin D. The largest increase in vitamin D declines occurred between 12 and 18 months, when the percent of toddlers not meeting their RDA increased from $37.7 \%$ to $60.5 \%$ resulting in a $23 \%$ decrease from the 
previous age. There were also inadequacies in iron and calcium intake. At twelve months, inadequate iron intake reached $46 \%$, but then dropped to $25 \%$ at twenty-four months. The range of calcium inadequacies was from $17 \%$ to $22 \%$ at nine and twentyfour months.

In general, the infants in this study showed to have an adequate diet. There are some problematic areas concerning zinc and vitamin D. These two nutrients were found to be low at almost each visit, but it is hard to determine any applicable results from the average intake of these nutrients. The low levels of vitamin D occurred at the older ages, at the time when the children are being weaned off of the infant formula, which is rich in vitamin D. The zinc intake was a larger problem during the subjects' second year of life because the intake level of zinc declined. These are two areas that need to be monitored to help infants achieve maximum nutrition and growth.

Skinner et al. (1997) looked at the nutrient and food intakes of healthy, white infants. The purpose of this study was to compare the nutrient intakes of the infants to current recommendations. The subjects were 98 infant-mother pairs who were recruited from two urban areas of Tennessee. The pairs were recruited using birth announcements and posters placed on various bulletin boards. Interviews were done at 2, 3, 4, 6, 8, 10, 12, 16, 20, and 24 months of age. A computer-generated program randomly chose 57 to 60 mother-infant pairs to be interviewed. During each interview, mothers completed a 24-hour recall of the infant's food intake, formula, breast milk, and vitamin supplements. At month eight's interview, mothers were asked about the foods their child ate nearly everyday and those that were the infant's least favorite. Weights, lengths, and head 
circumferences were measured at each visit to ensure that the infant's were growing normally.

A volume of $750 \mathrm{ml} /$ day was used for exclusively breast fed babies for nutrient calculations. For infants that were both breast and formula fed, the amount of formula consumed was subtracted from $750 \mathrm{ml}$. Mean energy and nutrient intakes for each interview age were calculated and compared against the RDA for that age. Nutritionist IV software was used to perform nutrient calculations.

The results showed that 51 of the subjects were males and 47 were females. Most mean weights, lengths, and head circumferences for males and females were within the $25^{\text {th }}$ and $95^{\text {th }}$ percentiles compared to National Center for Health Statistics standards. There were three nutrients that tended to be low at most ages. The table below shows nutrients that were low at various ages.

Table 3 : Low nutrients for Skinner et al study

\begin{tabular}{|l|r|r|r|r|r|}
\hline Age(months) & $\mathbf{2}$ & $\mathbf{6}$ & $\mathbf{1 6}$ & $\mathbf{2 0}$ & $\mathbf{2 4}$ \\
\hline Zinc \% of RDA & 51 & 80 & 49 & 51 & 60 \\
\hline Vitamin D \% of RDA & 60 & 73 & 46 & 49 & 43 \\
\hline Vitamin E\% of RDA & & & 58 & 60 & 48 \\
\hline
\end{tabular}

Fat consumption decreased from 6 months at 40\% of energy to 30-32\% of energy at 10 to 24 months of age. Favorite foods of the infants included cheese, crackers, sweet potatoes, and yogurt for ages 12 to 16 months. The least favorite foods were from the vegetable group.

This study shows that mean intake of zinc, vitamin D, and vitamin E intakes were low at various ages. It also noted the decreased amount of fat consumption in these infant's diets. Fat is important for brain development early on in life. Vegetables and 
meats tended to be the least favorite of foods for these ages. Increased vegetable and meat consumption could help increase the nutrient density of infants' and toddlers' diets.

Another factor that is important with a young child's nutrition and health is the time at which you begin to introduce complementary foods into the diet. Complementary foods are new foods that are that are introduced to a child along with his/her formula or breast milk.

A study focused on the time at which these foods are introduced and the effect the timing had on iron and zinc status (Kattelmann, Ho, and Specker, 2001). It is recommended that additional foods be added to an infant's diet at about six months of age.

The subjects in this study on introducing complementary foods were 172 infants that had no cardiac, respiratory, hematological, hepatic, gastrointestinal, or bone disease. The infants were divided into two groups: one in which complementary foods were added early at ages 3 to 4 months and the other in which complementary foods were added later at age 6 months. Of the 172 infants enrolled, 133 completed the study. The infants in the early group were introduced to foods between three and four months. The late group was introduced to the foods when they were six months of age. All of the participants were fed infant formula. To be eligible for the study, the infants had to be on formula by three months of age. The subjects' length, weight, and head circumference were measured. Three-day diet records were collected at 3, 6, 12, 18, 24, 30, and at 36 months. Also, one-day records were collected at 4, 5, 7, 8, 9, 10, and at 11 months. The parents were given both oral and written descriptions on how to record the foods and amounts. The records were then looked over by a registered dietitian. The University of 
Minnesota Nutrition Coding Center's nutrient database was used to analyze the nutrients in the foods. The average number of meat feedings was recorded from the 12, 24, and 36-month diet records. Blood was taken at 12, 24, and 36 months for hemoglobin mean corpuscular volume, serum ferritin and zinc levels.

The results showed that the early group had an average higher iron intake at 4, 5, and 6 months of age than did the later group. There were no significant differences in iron status after six months of age. At 12 months the average for both groups were above the RDA for iron, but neither group was above the RDA for iron at 18 months and later. For zinc, the late group consumed a little more zinc than did the early group at 5 and 6 months. This was the only significant difference in zinc. Average zinc intakes were a little below the RDAs until eleven months in both groups and at twelve months both groups were only receiving $50-60 \%$ of their RDA.

These results showed that many infants are not receiving adequate amounts of zinc and at certain times not enough iron. This finding is important and it shows that the timing of introducing complementary foods really does not have much effect on the nutrient status of the infants. Yet, adding foods at the young age of 3 to 4 months is not recommended.

\section{Typical content of infants and toddlers diets}

It is important to determine what a typical infant and toddler consume. The studies reviewed in this section give us insight into what types of foods infants and toddlers like to eat and what types of food the parents are giving them.

Hunt and Meacham, 2001 performed a study to estimate the amounts of twelve different minerals in commonly ingested foods for several different age groups. The 
minerals measured were aluminum, boron, calcium, copper, iron, magnesium, manganese, molybdenum, phosphorus, potassium, sodium, and zinc. This study is important in showing the children's needs for theses nutrients and to provide new information for upgrading and establishing more accurate recommendations. The agesex groups were as follows: infants (6-11 months), toddlers (aged 2 years), male and female adolescents (14-16 years), adults (25-30), and seniors (60-65 years). These groups were used to determine estimated intakes.

A model, which is used for estimating dietary mineral intakes, was modified and used for this study. The model uses 234 identified foods that are common in the US diet. The foods were analyzed for the content of the minerals listed above for foods that are commonly ingested by the different age groups. This was an estimate of the minerals obtained from foods that are commonly eaten. The groups of foods in the model are as follows: milk/cheese, meat/poultry, eggs, legumes/nuts, grains, fruits, fruit drinks, vegetables, mixed dishes/meals, fats/dressings, sweeteners/catsup, desserts, beverages, and infant foods. Average daily intake of the minerals that were analyzed was determined based on the average daily intake of the foods that were analyzed.

The results for the infant group showed that infant foods supplied $47 \%$ of the boron, $49 \%$ of manganese, $33 \%$ of the calcium, $37 \%$ of the zinc, $48 \%$ of the copper, 77 $\%$ of the iron, and $15 \%$ of the aluminum intake. The milk/cheese group contributed $25 \%$ of the magnesium, $32 \%$ of the phosphorus, $29 \%$ of the sodium, and $28 \%$ of the potassium. The milk/cheese group also provided a significant amount of calcium.

The results for the toddlers showed that $38 \%$ of the boron came from fruits and fruit juices and another higher percentage came from vegetables. The milk/cheese group 
provided a large percentage of the calcium, $34 \%$ of the magnesium, $42 \%$ of the potassium, and $48 \%$ of the phosphorus. Grains contributed the highest amount of iron than the other food groups for the toddlers.

These numbers show that many different kinds of foods and food groups contribute to all of the minerals needed in our diets. This study shows that a variety of foods are needed to obtain the proper nutrients for infants and toddlers.

Ganji et al. (1995) did a study to determine the nutrient intakes of children of various ages by using diets reported in 1987-88 Nationwide Food Consumption Survey (NFCS). There were three different age groups studies, but the age group relevant that was studied is ages 1-3 years. The NFCS used the probability area sample from the 48 conterminous states. Dietary intakes were collected for three consecutive days by using a 2-day dietary record and a 1-day dietary recall. Nutrient compositions of the diets were analyzed by a nutrient database developed by the Human Nutrition Information Service. The values for the different components measured came from the USDA Nutrient Data Base for Standard Reference. Many nutrients were analyzed including: energy, fats, cholesterol, carbohydrates, protein, vitamin A, C, E, B-6, and B-12, thiamin, riboflavin, niacin, folic acid, calcium, phosphorus, magnesium, iron, copper, zinc, sodium, and potassium. The participants in the 1-3 age group were 280 males and 257 females.

The results show that children of all ages consumed low levels of energy relative to the 1989 RDA. Intakes for the 1-3 age group were total fat 42g, cholesterol 158mg, carbohydrates 135g, and protein 41g. Vitamin E and zinc intake for all age groups were below the RDA. Also in the 1-3 age group mean intakes of iron and calcium were 58\% and $84 \%$ of the RDA. 
The results of this study showed that energy, Vitamin E, and zinc were low in the 1-3 age group. Some of these low levels could be possibly due to underreporting. The low intake of vitamin E, calcium, iron, and zinc that was found in this study does raise some concern. This study showed that there is still improvement that could be made in young children's diets to help meet all of their nutritional needs.

\section{Overindulgences}

An additional factor to look at with a child's nutrition is fat and protein content in their diets. Since milk is the primary source of nutrients in the first several months of life, it is important to have an understanding of the contents of the milk and how close it comes to providing recommended values for the children.

A study examined how different diets using milk and milk products with varying amounts of fat and protein contribute to a child's diet (Svahn, Axelsson, and Raiha, 1999). The subjects for this study were fifty-four infants that consisted of thirty-three girls and twenty-one boys that were recruited from child health centers in Malmo, Sweden. The children were born between August of 1992 and September of 1995. They were enrolled in a controlled prospective study at eleven months old. All of the participants were breast fed from birth. By the time all of the children were twelve months old, they had been weaned from breast milk. During the time the children were breast fed, if the breast milk was not available standard infant formula was provided. The subjects were divided into one of the four milk groups randomly. The groups were: Lowfat (LF) milk with milk fat content $1.0 \mathrm{~g} / \mathrm{dl}$ and protein $3.3 \mathrm{~g} / \mathrm{dl}$, standard-fat (SF) milk with milk fat $3.5 \mathrm{~g} / \mathrm{dl}$ and protein $3.3 \mathrm{~g} / \mathrm{dl}$, Partially vegetable fat and protein reduced (PVF) with fat content at $3.5 \mathrm{~g} / \mathrm{dl}$ and protein content at $2.2 \mathrm{~g} / \mathrm{dl}$, and the full-vegetable 
fat (FVF) with fat at $3.5 \mathrm{~g} / \mathrm{dl}$ and protein at $3.0 \mathrm{~g} / \mathrm{dl}$. For the PVF group, the milk fat came from 50\% milk fat and 50\% rapeseed oil, and for the FVF group, the fat came from $100 \%$ vegetable fat.

The LF and SF milks were used as reference diets. The milks were provided free by the investigator and were ready to serve. These were the only milk formulas fed to the children. There was no other food restriction for the participants except for the dairy products. The parents did a seven-day dietary record before the new diets began. Again at fifteen and seventeen months, the recordings were repeated. The parents were to record the child's food intake precisely and the intakes were recorded by tablespoons, teaspoons, deciliters, grams, or pieces. If the child was going to be at a daycare, instructions were given to the staff about recording the diets of the children properly. Anthropometrics were completed at 12, 15, and 18 months by the same pediatric nurse. Nutrient and energy intakes were calculated by using the MAT's computer program. This program uses the Swedish National Food Administration's food consumption tables for comparison.

Of the fifty-four children who began the study, thirty-eight completed it. The results showed that in regards to energy intake, the different milk groups did not statistically differ. Although there weren't any significant differences in protein intakes between the groups at twelve months of age, at fifteen and eighteen months there were some differences. Protein intakes went up in the LF and SF groups between twelve and fifteen months, but there was no increase in the PVF and FVF groups. The LF group had the highest intake of protein. For fat intake in the LF group, intake decreased at fifteen months from $36.2 \mathrm{~g} /$ day to $29.7 \mathrm{~g}$ /day and at eighteen months to $34.8 \mathrm{~g}$ /day. The SF group 
had the highest fat consumption, $46.2 \mathrm{~g} /$ day at 18 months. Saturated fat in the SF group increased to $19.6 \%$ of energy at 15 months of age. The LF, PVF, and FVF groups had significantly lower values of saturated fat at 15 and 18 months. There was only a small increase in total fat intake in the PVF and FVF groups. Also, there were no significant differences in anthropometrics.

This study showed that the children that were on full fat milk diet and dairy products with lower milk fat and high vegetable fat had a lower value of saturated fats and higher monosaturated and polyunsaturated fat. This is compared to children that were fed milk with $100 \%$ milk fat milk and dairy products. On the other hand, subjects who were on the low fat milk and dairy products diet, had a lower intake of saturated fats, but they were not receiving $30 \%$ of their energy from fat. There were no harmful side effects in the children's growth related to a low milk fat diet or a low protein diet. There were also no substantial differences in energy consumption among the different groups.

The recommended protein intake according to the $\mathrm{FAO} / \mathrm{WHO} / \mathrm{UNU}$ for children of twelve months is $1.26 \mathrm{~g} / \mathrm{kg}$ day. The children in the LF and SF group exceeded this amount at both fifteen and eighteen months. This is due to the high protein amounts in the milks that the children were consuming.

In spite of the different types of milk diets the children were consuming, there were no harmful effects on the growth of the children. On the reverse, there were no signs of increased growth in the children who were on the SF milk diet. The differences in fat and protein in the children can be linked with the different types of milk diets they were consuming. The study concluded that a diet with full fat cow's milk or low fat cow's milk provided too much protein and either too high fat or too low fat. A more 
advantageous milk diet would be one that was of protein-reduced milk with either $100 \%$ or $50 \%$ vegetable fat. This would help the children to be closer to recommended values for both protein and fat.

The study described previously done by Nolan et al. also had a result that showed intakes of protein that was beyond the recommended amount (Nolan et al. 2001). This study was analyzing protein, calcium, iron, zinc, and vitamin D in infants of various ages from low-income families. The trend that was common in the infants was high protein consumption. At all ages, the mean total protein intake was higher than the RDA. At 24 months of age the average protein intake was four times that of the RDA.

\section{Summary of problematic nutrients}

There were four main nutrients that were found to be problematic in the studies discussed previously. Specifically, vitamin E, iron, zinc, and vitamin D. These nutrients are considered problematic in the review of literature because the study participants appear to not be meeting the recommended intake values.

Lower intake of vitamin $\mathrm{E}$ is important because it is an antioxidant that ties up free radicals in the body that can be dangerous to our health (Groff and Gropper, 2000). However, vitamin E deficiency occurs rarely in humans.

Alternately, iron is often deficient in infants, toddlers, and young children between the ages of six months to four years of age. Some symptoms of iron deficiency include behavioral disturbances, impaired performance with some cognitive tasks, and short attention span (Groff and Gropper, 2000). It is important to note that iron deficiency can occur with, or without, anemia. One reason for this is that anemia 
typically does not occur until iron stores are severely depleted. Therefore, iron deficiency does not always occur with anemia.

Next, zinc is a mineral that is important to our bodies because it is a component of many metalloenzymes. This means that zinc provides structural integrity to the enzyme. It also functions in gene expression, cell replication, and in membrane stabilization. Therefore, a deficiency in zinc can result in growth retardation, skeletal abnormalities, impaired immune function, and delayed sexual maturation in children.

Finally, vitamin D, a vitamin that is important in bone health, functions to maintain homeostasis of blood calcium concentrations with parathyroid hormone (PTH). Moreover, vitamin D is also an important factor in gene transcription. Deficiency in children in vitamin D can result in rickets, which is characterized by failure of the bone to mineralize. 


\section{Statement of the Problem}

There have been several important points that have arisen from the literature review. One is that the WIC program can be helpful in improving the diets of young children. WIC has shown that it can have a positive effect of increasing nutrient quality of children's diets.

In several of the studies there were a few common themes that arose. One is that both iron and zinc intakes were below RDA requirements. This is an important finding to be aware of, because if EARs were used instead of RDAs, the findings may have turned out differently or would the children's diets still be lacking in these nutrients? However, it is preferable to use EARs because a RDA is set two standard deviations above the EAR. Thus, an EAR would be closer to the children's needs.

Other nutrients that were found to be lacking in the children's' diets were vitamin $\mathrm{D}$, vitamin E, and calcium. It appeared that as a child was getting older, he/she began consuming less vitamin $\mathrm{D}$, vitamin $\mathrm{E}$, and sometimes calcium. This seems to be related to the decline in drinking formula or breast milk and transitioning the infant into a toddler type diet.

Each of these nutrients is important for a child to grow and develop properly.

However, throughout the literature reviewed they appear to be problematic because children's intakes appear to be below suggested intake levels. 


\section{Chapter 3}

\section{Methodology}

\section{$\underline{\text { Recruitment }}$}

For this study, a cross-sectional design was used. The participants were healthy children between 6-24 months of age enrolled in the Special Supplemental Nutrition program for Women, Infants, and Children (WIC) in ten West Virginia counties. The West Virginia counties that were used were Braxton, Calhoun, Greenbrier, Gilmer, Jackson, Mason, Mineral, Morgan, Pleasants, and Ritchie. The participants in this study were of low income, because to be eligible for WIC there are certain income guidelines used. See Appendix A for WIC income guidelines. The data were collected from July 2001 through summer of 2003.

During regular WIC appointments, a WIC nutritionist would inform the parents of eligible children of the study. Any who were interested in the study were given a stamped addressed postcard to be mailed to the study coordinator. When the study coordinator received the postcard, a research assistant called the parents and set a meeting time at their local WIC clinic.

Written consent was obtained from the parents of the children to be a participant in the study. The WVU Institutional Review Board for the protection of Human Subjects approved this study. See Appendix B for consent form and study flyer.

Participants for this study were children who were ages 5.5-26 months of age that were eligible to be in the WIC program. Children who had an infection or had a disease 
at the time that blood was drawn were not included in the study. Blood results can be found in Cannon’s 2003 thesis. (Cannon, 2003)

\section{$\underline{\text { Appointment with a Research Assistant }}$}

The research assistant collected the child's height and weight, executed a multi pass 24-hour recall for each child's diet and instructed the caregiver of the child as to where to get a blood sample drawn during their appointment. The guardian provided information about the child's dietary patterns and their medical history. Information on vitamin/mineral supplementation was obtained. Additionally, within one week another 24-hour dietary recall on each child was obtained via telephone using the same method mentioned previously. A check of $\$ 40.00$ was given to the parents of the children in the study for compensation after they had met with the research assistant.

\section{Data Collection Form}

A Data Collection form (See Appendix C) was used to obtain certain information for each child. The information collected included gender, height, weight, date of birth, gestation length, diseases, history of chronic illnesses, allergies, food intolerances, medications, surgeries, and any existing nutritional deficiency.

\section{Diet History Form}

The Diet History Form (Appendix D) was used to collect information regarding appetite, vitamin and mineral supplementation, past two weeks illness, age, weight, water type, and several nutrition related questions regarding the child's past eating habits.

\section{Dietary Assessment - Multiple Pass 24-Hour Dietary Recall}

While performing the multiple pass 24-hour dietary recall, the research assistant followed a written script (Appendix E and F) to acquire the dietary recall for each child. 
The first pass consisted of obtaining a list of foods consumed by the child from the parent the previous day. In the second pass, information was collected on the time and occasion (breakfast, lunch, dinner, snack) that the food was eaten. The final pass gained the specific information about how much of the food was consumed. Measuring spoons and utensils were used to help determine the correct portion size. These were provided for demonstration for the caregivers to ensure that the portion sizes were recorded properly. Within the next week after the appointment the research assistant, using the same script previously mentioned, acquired a second 24-hour recall via phone. Also information of vitamin and or mineral supplementation was obtained.

$\underline{\text { Analysis of diet }}$

Both 24-hour dietary recalls were analyzed for every participant. A research assistant entered the diets into Food Processor for Windows Version 7 (ESHA Research, 2001). The analysis showed an average of two days of dietary intake for each participant. Intakes of each nutrient were calculated and compared to current intake recommendations for each child in their age group.

\section{Dietary Variety}

Each child was scored on their dietary variety from the different food groups. They could receive a score of 1, 2, 3, or 4 for their diets. They got a point if they were eating from each of the following food groups: 1.) Fruits/vegetables group 2.) Meat group 3.) Bread, cereal, grain group 4.) Milk, formula, or breast milk. The highest score was a four indicating that the child was consuming foods from all four groups listed above. The lowest score was a one meaning that the child was only eating from one of the groups. 


\section{$\underline{\text { Z scores }}$}

Weight for Age Z-score (WAZ and HAZ) and for Weight for Height Z-scores (WHZ) were determined using the 1985 CDC/WHO growth reference curves. These calculations were done by using the EpiInfo computer program (CDC, Atlanta GA, 2000). Information for this program was based on growth curves that were developed by the National Center for Health Statistics and the CDC. The curves were based on data collected from the Fels Research Institute and US Health Examination Surveys. $\underline{\text { Statistical analysis }}$

Each nutrient analyzed for every child has been compared to the DRI for that nutrient. Either the EAR or the AI was used for comparison, depending on which DRI was available. This gives a count of how many children are not meeting the DRI and a percentage of the amount of each nutrient consumed for the child. This procedure will show us how much of each nutrient the children are receiving through their diet and if they are lacking in any nutrient.

A large part of the analyses performed were based on descriptive statistics. Group means, medians, and standard deviations were calculated for each nutrient for each child. Group means, medians, and standard deviations for height and weight were calculated.

Chi square tests and Fisher's exact test were used on each nutrient for both groups combined and for each separately compared to the children's dietary variety score. These tests were performed on SAS 8.00 (SAS Institute, Cary NC, 1999). The children's diets were rated on a score of $1,2,3$, or 4 in relation to the different food groups they were consuming. The children would get one point for each of the following food groups 
incorporated in their diets: 1. Meat, fish, and poultry, 2. Milk, formula, or breast milk, 3. Fruit and vegetables, and 4. Bread, cereal, or starch group.

Correlations were also done to determine if there were any relationships between the WAZ score, WHZ score, and intake of protein. Correlations were done with WAZ score, WHZ score, meat servings and total energy (kcals). 


\section{Chapter 4}

\section{Results}

\section{Sample Characteristics}

Eighty-seven participants were enrolled in this study. Participants included fortyfive boys and forty-two girls. The range of the ages was six months through twenty-eight months of age. The mean ages, mean weight, and mean height are recorded in table 4 for the two different groups and for both groups combined. The participants in this study were all white children who were enrolled in the WIC program.

Table 4: Sample Characteristics

\begin{tabular}{|l|l|l|l|}
\hline & $\begin{array}{l}\text { 6-11.9 months } \\
(\mathrm{n}=32) \\
\text { Boys=19 } \\
\text { Girls=13 }\end{array}$ & $\begin{array}{l}\text { 12-28 months } \\
(\mathrm{n}=55) \\
\text { Boys=26 } \\
\text { Girls=29 }\end{array}$ & $\begin{array}{l}\text { Total of both } \\
\text { groups }\end{array}$ \\
\hline Mean age & 7.7 months & 18.2 months & 13.96 months \\
\hline $\begin{array}{l}\text { Mean weight } \\
\text { (pounds) }\end{array}$ & $19.13+/-2.74$ & $25.44+/-3.74$ & $23.12+/ 4.56$ \\
\hline $\begin{array}{l}\text { Mean height } \\
\text { (inches) }\end{array}$ & $27.51+/-1.37$ & $31.82+/-2.99$ & $30.23+/-3.27$ \\
\hline
\end{tabular}

\section{County Description}

The ten counties used for this study, Braxton, Calhoun, Greenbrier, Gilmer, Jackson, Mason, Mineral, Morgan, Pleasants, and Ritchie, are shown on a map of West Virginia in Appendix E. These counties are representative of many Appalachian counties in the state of West Virginia. These counties are located in different areas of the state. This gives us a sample that represents each area. Some of the counties were from the northern, southern, eastern, western, and central part of the state. The counties in which the data were collected are rural counties with most of the population being Caucasian. 
See Appendix $G$ for location of the eight counties in West Virginia where the data for this study was collected.

\section{Nutrient Data:}

Tables 5 and 6 below, show the means, medians, standard deviation, and the number of children that were not meeting the Dietary Reference Intakes for each nutrient in groups 1 and 2. In group 1, vitamin D, pantothenic acid, selenium, and manganese were the nutrients that had the most participants whom were not meeting the DRIs. Forty-three point five percent of the children in this group were not meeting their vitamin D needs. Children were not meeting their needs for the following nutrients as well: $72 \%$ for pantothenic acid, $87.5 \%$ for manganese and $43 \%$ for selenium in this group were not meeting the DRIs. For group 1, fat consumption was 30\% or more of the children's total kilocalories.

In group 2, vitamin $\mathrm{E}$ and manganese were the problematic nutrients. Sixty percent of the children were not eating adequate vitamin $\mathrm{E}$ and $74.5 \%$ were not consuming enough manganese. The participants in group 2 were receiving more than $30 \%$ of their total kilocalories from fat compared to group mean intakes for fat. 
Table 5: Group 1 Nutrient Data

\begin{tabular}{|c|c|c|c|c|}
\hline \multicolumn{5}{|c|}{ Group 1} \\
\hline & Mean & Median & SD & \# below DRI \\
\hline \multicolumn{5}{|l|}{ Nutrient } \\
\hline Vit A (RE/d) & 1177.69 & 1063.29 & 485.052 & 0 \\
\hline Thi mg/d & 0.855 & 0.81 & 0.404 & 2 \\
\hline Rib mg/d & 1.347 & 1.34 & 0.567 & 2 \\
\hline $\mathrm{NE}$ mg/d & 11.974 & 10.6 & 5.271 & 2 \\
\hline B6 mg/d & 0.877 & 0.7 & 0.477 & 2 \\
\hline B12 mcg/d & 2.126 & 2.14 & 0.997 & 2 \\
\hline Vit C mg/d & 62.702 & 128.82 & 62.702 & 2 \\
\hline Vit D mcg/d & 6.244 & 6 & 4.997 & 14 \\
\hline Vit E mg/d & 14.488 & 14.01 & 60.67 & 1 \\
\hline Folate mcg/d & 125.77 & 116.14 & 54.01 & 4 \\
\hline PA mg/d & 1.586 & 1.14 & 1.315 & 22 \\
\hline Ca mg/d & 591.429 & 555.55 & 239.129 & 2 \\
\hline $\mathrm{Cu} \mathrm{mg} / \mathrm{d}$ & 0.666 & 0.61 & 0.207 & 0 \\
\hline Fe mg/d & 13.998 & 12.67 & 6.732 & 2 \\
\hline $\mathrm{Mg} \mathrm{mg} / \mathrm{d}$ & 98.98 & 86.59 & 38.729 & 11 \\
\hline $\mathrm{Mn} \mathrm{mg} / \mathrm{d}$ & 0.239 & 0.11 & 0.384 & 28 \\
\hline $\mathrm{P}$ mg/d & 463.09 & 437.7 & 200.931 & 5 \\
\hline Se mg/d & 23.75 & 20.7 & 9.56 & 1 \\
\hline $\mathrm{Z} \mathrm{mg} / \mathrm{d}$ & 6.461 & 6.13 & 2.959 & 2 \\
\hline Protein g/d & 21.505 & 20.58 & 8.486 & \\
\hline Energy kcal/d & 913.7 & 883.05 & 276.795 & \\
\hline $\mathrm{CHO}$ g/d & 122.488 & 114.85 & 37.877 & \\
\hline Fat g/d & 38.305 & 37.81 & 12.95 & \\
\hline
\end{tabular}

Table 6: Group 2 Nutrient Data

\begin{tabular}{|l|r|r|r|r|}
\hline \multicolumn{5}{|c|}{ Group 2 } \\
\hline & Mean & Median & SD & \# below DRI \\
\hline Nutrient & & & & 0 \\
\hline Vit A (RE/d) & 849.332 & 807.675 & 397.535 & 1 \\
\hline Thi mg/d & 1.082 & 0.985 & 0.474 & 0 \\
\hline Rib mg/d & 1.871 & 1.775 & 0.741 & 0 \\
\hline NE mg/d & 19.152 & 18.11 & 7.646 & 0 \\
\hline B6 mg/d & 1.176 & 1.105 & 0.525 & 2 \\
\hline B12 mcg/d & 3.708 & 3.085 & 2.59 & 4 \\
\hline Vit C mg/d & 101.218 & 94.135 & 91.912 & 14 \\
\hline Vit D mcg/d & 9.075 & 7.315 & 5.351 & 33 \\
\hline Vit E mg/d & 5.487 & 3.745 & 5.041 & 10 \\
\hline Folate mcg/d & 200.77 & 166.1 & 113.67 & 6 \\
\hline PA mg/d & 3.403 & 3.01 & 2.122 & 3 \\
\hline Ca mg/d & 1051.691 & 1095.76 & 483.901 & SD \\
\hline Nutrient & Mean & Median & \# below DRI \\
\hline
\end{tabular}




\begin{tabular}{|l|r|r|r|r|}
\hline Cu mg/d & 0.484 & 0.45 & 0.247 & 0 \\
\hline Fe mg/d & 10.589 & 9.155 & 5.308 & 1 \\
\hline $\mathrm{Mg} \mathrm{mg/d}$ & 156.824 & 148.565 & 56.484 & 1 \\
\hline $\mathrm{Mn} \mathrm{mg/d}$ & 0.993 & 0.81 & 0.673 & 41 \\
\hline $\mathrm{P} \mathrm{mg/d}$ & 942.525 & 880.13 & 353.001 & 0 \\
\hline Se mg/d & 43.78 & 40.24 & 20.52 & 1 \\
\hline Z mg/d & 6.497 & 5.83 & 3.478 & 2 \\
\hline Protein g/d & 51.63 & 49.7 & 20.53 & \\
\hline Energy kcal/d & 1312.369 & 1289.93 & 393.1611 & \\
\hline CHO g/d & 165.168 & 160.49 & 51.203 & \\
\hline Fat g/d & 51.245 & 50.41 & 19.301 & \\
\hline
\end{tabular}

\section{Dietary Variety and Adequacy}

To show a relationship between dietary variety and adequacy Fisher’s Exact Test and Chi Square were used for group 1, group 2, and both groups combined. These tests were used to determine if children with greater dietary variety were more likely to meet adequacy of the nutrients. The results were significant if the P value was less than .05 for a nutrient. The children could receive a score of 1-4. A score of four indicates that the child is eating food from each food group. Children with a high dietary variety score were more likely to have adequate intakes of magnesium $(\mathrm{P}=.0107)$, riboflavin $(\mathrm{P}=.0454)$, vitamin $\mathrm{B}-6(\mathrm{P}=.0454)$, and selenium $(\mathrm{P}=.0013)$. For magnesium, riboflavin, vitamin B-6, and selenium, the majority of the children who were below the DRI did not have a high score for dietary variety.

For Group 1, phosphorus was only nutrient that had a P value less than .05. The $\mathrm{p}$ value for phosphorus was .0210, with five infants not meeting the DRI and of those five only one had a score of 4 for dietary variety.

For Group 2, folate was only one nutrient that had a p value less than .05. Nine children did not meet their DRI for folate and 4 out of those 9 children had a dietary variety score of 4 . The p value was .0260 for folate in this group. 
For this sample, no children had a score of one. Only five children had a score of two. The majority of the children had a score of three or four. Thirty-two children had a score of 3 and 40 children had a score of four. Their high dietary variety scores indicated that the children were eating a balanced diet from different food groups.

\section{Z-scores}

Table 7 shows descriptive statistics for WAZ and WHZ scores. For WHZ scores, zero children were below the two standard deviations below the median and nine children were above the two standard deviations. For WAZ scores, zero children were below the two standard deviations below the mean and six were above the two standard deviations above the median.

Table 7: Z scores

\begin{tabular}{|l|l|l|}
\hline & WAZ & WHZ \\
\hline Median & .05 & -.85 \\
\hline Mean & .2486 & -.85 \\
\hline Standard Deviation & 1.117 & .2687 \\
\hline
\end{tabular}

\section{Correlations}

There were no significant correlations between grams of protein and WAZ and WHZ scores in either age group or age groups combined. There were also no significant correlations between energy and WAZ and WHZ scores in any of the groups. The positive correlations are shown in table 8. The only significant correlations were between energy and the number of meat servings.

Table 8: Correlations between number of meat servings and total energy intake 


\begin{tabular}{|l|l|l|}
\hline Age group & Correlation & P value \\
\hline One & .38208 & 0.0495 \\
\hline Two & .51965 & $<0.0001$ \\
\hline Both & .67098 & $<0.0001$ \\
\hline
\end{tabular}




\section{Chapter 5}

\section{Discussion}

One of the aims of this study was to describe dietary variety of the infants' and toddlers' diets. The children could have received a score of 1-4 for their dietary variety. A score of 4 indicates that the children are eating from the bread/cereal, fruit/vegetable, meat, or milk/formula/breast milk groups. If the children receive a score of 3 , 2, or 1 then this means that they are eating from that number of food groups.

The main factor in determining if there is a relationship between dietary variety and a specific nutrient was the children's dietary variety score. Of the children that were not meeting recommendations for nutrient intakes, they were found to have a relationship with dietary variety. The majority of the children that were found to have a relationship with dietary variety did not have a high total dietary variety score.

The children in this study were typically eating good diets. The majority of the children had a high dietary variety score, which indicated that they were consuming foods from all or most of the food groups. The infants and toddlers high dietary variety scores may reflect the WIC program in itself. The WIC program gives food vouchers for milk or formula, $100 \%$ fruit juice, cereals that have a high iron content, and beans and peanut butter to those who qualify for the program. These food vouchers help supplement a child's diet. Therefore, this may be a reason why the dietary variety scores were good for this sample of children.

When comparing dietary variety with adequacy for a certain nutrient, there were only a few nutrients that were found to be significant. This again is an indicator that the WIC program plays a role in helping children consume adequate nutrients. Not only do 
the participants of this program receive food vouchers, but they also participate in classes and counseling dealing with proper nutrition. This is an added benefit for the participants that are in the WIC program.

Another objective of this study was to examine which nutrients the children were low in meeting the DRI. For group one, there were four nutrients that the children were more likely to not meet the DRI.

The first nutrient in group one that was problematic was vitamin D. Vitamin D is an important part of the diet. It has many functions including homeostasis maintenance between phosphorus and calcium and in bone health (Mahan and Escott-Stump, 2000). A deficiency in vitamin D can lead to rickets in children. Sunlight is a good source of vitamin D, as are fortified milk products. Formula, fish, and egg yolk are other sources of vitamin D.

The children may have been getting vitamin D from sunshine as their main source, but that was not measured in this study. Since the children in this group were between six and 11.9 months, they were most likely still on formula and had not been introduced to fortified cow's milk, which is a good source of vitamin D, although formula is also a good source of vitamin D.

Nolan et al (2002) found that at nine and twelve months of age vitamin D intake levels were lower than the set RDA. This study also used subjects that were eligible for the WIC program and a 24-hour dietary recall at each visit. This study looked at infants and toddlers beginning at 3 months of age to 24 months of age.

Skinner et al (1997) also found that at six months of age vitamin D intake was low compared to the RDA. At this age the children were only consuming $73 \%$ of the RDA 
for vitamin D. This study looked at children from 2 months of age though 24 months of age. One 24-hour dietary recall was collected at each visit and the children used in this study were of middle-upper class compared to the lower class population that was used for our study.

Pantothenic acid is the next nutrient that was low in group 1. Pantothenic acid is a B-vitamin that is needed for normal growth, physiological, and reproductive functions (Groff and Gropper, 2000). It is a precursor for coenzyme A and acyl carrier protein, which are used in fatty acid synthase. Pantothenic acid is found in most foods that we consume. As mentioned previously, many of these infants were still on formula. The formula that they were consuming did contain some pantothenic acid, but many of the children were being introduced to other foods at the time of this study and may have been drinking less formula. Finally, the database used may not have contained proper pantothenic acid contents for the foods and formula consumed by the children. All of these things may have contributed to the low-recorded intake of pantothenic acid.

Selenium is the third nutrient that was likely to be low in the diets of the younger infants. Selenium is a micromineral that is important in many parts of metabolism (Groff and Gropper, 2000). It is a cofactor for glutathione perioxidase, for pancreatic function, and for DNA repair and enzyme activation. A selenium deficiency has been linked to diseases such as Keshan which is characterized by cardiomyopathy. Selenium is found in the soil, so it is found in food plants that we consume. The amount of selenium in the soil will determine how much is found in the food. Organ meats, seafood, and fish containing mercury also contain selenium. 
The final nutrient that was low in group one was manganese. Manganese is a component of many enzymes including pyruvate carboxylase (Mahan and Escott-Stump, 2000). Manganese is also essential for reproduction. Good sources of manganese include whole grains, nuts, dried fruits, and leafy vegetables. Most of the infants in this age group are not eating these types of foods that are high in manganese. Although human milk is not a good source of manganese, most of the infants in this group were on formula, not breast milk. The content of manganese in fruits and vegetables is also related to how much is in the soil that the foods were grown in. Manganese deficiency is not common in humans unless it is left out of the diet completely.

In 2001, Hunt and Meacham conducted a study on how different foods and food groups contribute to mineral intake. For manganese, in infants' ages 6-11 months, infant foods supplied $49 \%$ of the total manganese consumed. This result shows that almost half of the manganese consumed in an infant's diet comes from infant foods.

An additional factor that may have affected the results for all of the nutrients that were low in group one is that an AI was used for comparison rather than an EAR. AIs are set at a higher level than EARs. There were no EARs set for this age group, therefore the AIs had to be used for comparison.

Manganese intake was low in group 2 as well. An AI was also used for measurement in this group as well. Since an AI is set to meet the needs of most individuals in a group, the children in this group may have been consuming as much manganese as they needed. The toddlers were consuming over $80 \%$ of the manganese according to the AI. This amount may be adequate to meet their manganese needs. 
Vitamin E is an antioxidant that terminates free radicals (Groff and Gropper, 2000). Good sources of vitamin E include vegetable based oils, margarine, mayonnaise, and some fruits and vegetables. Although many of the children in this group did not meet the EAR, the group mean shows that there were many children who were consuming adequate amounts of the recommended vitamin $\mathrm{E}$. Children at this age are more apt to consume the foods that vitamin $\mathrm{E}$ are in than the younger group because they are able to eat a wider variety of foods. The toddlers in this population may not have had access or been eating enough of these types of foods to meet their vitamin E needs.

Vitamin $\mathrm{E}$ intake was another nutrient that was low in the children in group two. An EAR was used for comparison for vitamin E. Picciano et al (2000), found that vitamin E consumption was below the RDA for ages 12-18 months and that the intake did decrease over time. Three-day dietary records were collected each month through the duration of the study. Skinner et al (1997), also found that vitamin E intake was low compared to RDAs for children 16, 20, and 24 months of age. In both of these studies a RDA was used for comparison to intake levels, whereas we used an EAR for comparison.

The WAZ and WHZ scores are recorded in Table 6. There were zero children for both WAZ and WHZ scores that were below -2.0 compared to the national standards. This indicates that the children were within the normal ranges for these growth parameters. This is a positive result because it shows that even though the children are of low economic status and are on the WIC program, they are still within normal ranges for growth parameters.

The final objective of this study was to determine if there were any relationships between WAZ scores, WHZ scores, servings of meat, with the total energy (kcals) 
consumed. Correlations (Table 9) were run with WAZ scores, WHZ scores with total grams of protein. The results showed that there were no significant correlations between WAZ and WHZ scores with grams of protein and total energy consumed. The only significant result was with meat servings and total energy. This makes sense because the servings of meat consumed by each child contribute to the total calories consumed.

There was a positive correlation between these two variables with each group analyzed separately and with both groups combined. 


\section{Chapter 6}

\section{Conclusion}

This study showed that there are some nutrients that infants and toddlers appear to be consuming in lower amounts than current recommendations. For the younger age group, vitamin $\mathrm{D}$, pantothenic acid, manganese, and selenium were the nutrients that were lacking. The older age group was low compared to current DRIs in manganese and vitamin E.

Another finding in this study was that dietary variety and inadequacy of certain nutrients are related for this sample. Magnesium, riboflavin, vitamin B-6, and selenium were all affected by dietary variety. It is important for children to consume foods from all of the food groups to help prevent inadequacies and deficiencies for each nutrient. This test shows the importance and the relationship between consuming the proper amount of nutrients and dietary variety.

The WAZ and WHZ scores of the children suggest that children enrolled in the WIC program in the counties studies, in Appalachia West Virginia are meeting national standards. No children were below two standard deviations of the median for weight for age and for weight for height. This is a good finding because it suggests that these children from low-income families are growing properly.

The infants and toddlers in this study were eating adequate diets. Most of the children were eating foods from the different food groups. Also, there were only a few nutrients that were low in this population's diet.

Further studies could be done to determine if diet transition has an impact on the nutrient content of these children's diets. Further research could be done on the content of 
minerals in the soil and how it affects nutrient content of fruits and vegetables. Vitamin D absorbed from the sun and vitamin D from foods could be examined to determine if individuals are getting enough from both diet and environment. Also, examination of the time and the type of complementary foods introduced could affect nutrient intake and density for this population. Complementary foods are those that are introduced to an infant along with his/her formula or breast milk.

In conclusion, the nutrient intake of children is important. Consuming the proper amounts of vitamins and minerals is essential in helping to prevent diseases and deficiencies and for overall good health. Consuming a good diet is an essential element for proper growth and development. 


\section{$\underline{\text { References }}$}

Cannon, MS. Dietary factors influencing iron status among WIC participants ages 6-24 months (thesis). Morgantown (WV) West Virginia University; 2003

Dean, a., Zubieta, J., Sullivan, K., and Delhumeau, C. (2000). EpiInfo Manual. Atlanta, GA: Centers For Disease Control and Prevention.

Food and Nutrition Board, Institute of Medicine. Dietary Reference Intakes for Calcium, Phosphorus, Magnesium, Vitamin D, and Fluoride. 1997. National Academy Press, Washington, DC.

Food and Nutrition Board, Institute of Medicine. Dietary Reference Intakes for Thiamin, Riboflavin, Niacin, Vitamin B6, Folate, Vitamin B12, Pantothenic Acid, Biotin, and Choline. 1998. National Academy Press, Washington, DC.

Food and Nutrition Board, Institute of Medicine. Dietary Reference Intakes for Vitamin C, Vitamin E, Selenium, and Carotenoids. 2000. National Academy Press, Washington, DC.

Food and Nutrition Board, Institute of Medicine. Dietary Reference Intakes for Vitamin A, Vitamin K, Arsenic, Boron, Chromium, Copper, Iodine, Iron, Manganese, Molybdenum, Nickel, Silicon, Vandaium, and Zinc. 2001. National Academy Press, Washington, DC.

Ganji, V., Betts, N., and Whitehead, D. Nutrient intakes of 1-3, 4-6 and 7-10 year age group children: Analysis of diets reported in 1987-88 Nationwide Food Consumption Survey. Nutrition Research. 1995;15:623-631.

Groff, J., and Gropper, S. (2000). Advanced Nutrition and Human Metabolism. Belmont, CA: Wadsworth/Thomson Learning.

Hunt, C. and Meacham, S. Aluminum, boron, zinc, calcium, copper, iron, magnesium, Manganese, molybdenum, phosphorus, potassium, sodium, and zinc: Concentrations in common Western foods and estimated daily intakes by infants; toddlers; and male and female adolescents, adults and seniors in the United States. Journal of the American Dietetic Association. 2001;101:1058-1060. 
Kattleman, K., Ho, M., and Specker, B. Effect of timing of introduction of Complementary foods on iron and zinc status of formula fed infants at 12, 24, and 36 months of age. Journal of the American Dietetic Association. 2001;101:443-447.

Mahan, L. and Escott-Stump, S. (2000). Krause's Food Nutrition and Diet Therapy. Philadelphia, PA: WB Saunders Company.

Nolan, K., Schell, L., Stark, A., and Gomez, M. Longitudinal study of energy and nutrient intakes for infants from low-income, urban families. Public Health Nutrition. 2002; 5:405-412.

Picciano, M., Smiciklas-Wright, H., Birch, L., Mitchell, D., Murray-Kolb, L., and McConahy, K. Nutritional guidance is needed during dietary transition in early childhood. Pediatrics. 2000;106:109-113.

Ponza, M., Devaney, B., Ziegler, P., Reidy, K., and Squatrito, C. Nutrient intakes and food choices of infants and toddlers participating in WIC. Journal of the American Dietetic Association. 2004;104:S71-S79.

Rose, D., Habicht, J., and Devaney, B. Household participation in the Food Stamp and WIC programs increases the nutrient intakes of preschool children. Journal of Nutrition. 1998; 128L548-555.

Skinner, J., Carruth, B., Houck, K., Coletta, F., Cotter, R., Ott, D., and McLeod, M. Longitudinal study of nutrient and food intakes of infants aged 2 to 24 months. Journal of the American Dietetic Association. 1997;97:496-504.

Svahn, J., Axelsson, I., and Raiha, N. Macronutrient and energy intakes in young children fed milk products containing different quantities and qualities of fat and protein. Journal of Pediatric Gastroenterology and Nutrition. 1999;29:273-281. 
APPENDICES 
APPENDIX A 
WIC Income Eligibility Guidelines

(effective April 1, 2000)

\begin{tabular}{|c|c|c|c|}
\hline $\begin{array}{c}\text { Household } \\
\text { Size }\end{array}$ & Weekly Gross Income & $\begin{array}{c}\text { Monthly Gross } \\
\text { Income }\end{array}$ & $\begin{array}{c}\text { Yearly Gross } \\
\text { Income }\end{array}$ \\
\hline 1 & $\$ 298$ & $\$ 1,288$ & $\$ 15,448$ \\
\hline 2 & $\$ 401$ & $\$ 1,735$ & $\$ 20,813$ \\
\hline \hline 3 & $\$ 504$ & $\$ 2,182$ & $\$ 26,178$ \\
\hline \hline 5 & $\$ 607$ & $\$ 2,629$ & $\$ 31,543$ \\
\hline \hline 6 & $\$ 710$ & $\$ 3,076$ & $\$ 36,908$ \\
\hline \hline 7 & $\$ 813$ & $\$ 3,523$ & $\$ 42,273$ \\
\hline \hline 8 & $\$ 917$ & $\$ 3,970$ & $\$ 47,638$ \\
\hline $\begin{array}{l}\text { Each } \\
\text { additional } \\
\text { person, add }\end{array}$ & $\$ 1,020$ & $\$ 4,417$ & $\$ 53,003$ \\
\hline
\end{tabular}


APPENDIX B 
Davis College of Agriculture, Forestry and Consumer Sciences

APR 102002

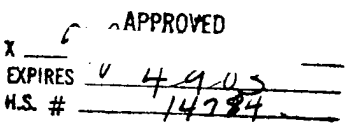

Factors Associated with Iron Deficiency among WIC Infants in Rural West Virginia

Introduction.

I,

to participate in a research study that examines the factors that are associated with iron deficiency among infants who are participating in the Special Supplemental Food Program for Women, Infants, and Children (WIC). Cindy Fitch, Ph.D., RD, who is conducting this research at West Virginia University, has explained the study to me. I understand that the money to pay for this study is being provided by the United States Department of Agriculture.

Purposes of the Study.

I understand that the purpose of this study is to learn more about the risk factors associated with iron deficiency and the relationships among iron, diet, lead poisoning, and infant growth and development.

\section{Description of Procedures.}

I understand that this study will be performed at the WIC clinic that my child attends and that approximately 600 children from around the state will be included in the study. If my child participates his/her length and weight will by measured. His or her mental development and motor skills will be measured by a series of tests that are designed for infants. I will be asked to give a history of my child's usual diet. A person who is experienced in drawing blood from infants will draw six milliliters (about 1 teaspoon) of blood from a vein. The amount of iron and lead in my child's blood will be analyzed in a laboratory. These results will be made available to me through the WIC nurse or dietitian and my child's personal care physician. I understand that if my child participates in this study, these interviews and measurements will require about 2 hours of my time.

\section{Benefits.}

I understand that this study is not expected to be of direct benefit to my child, but the knowledge gained may be of benefit to others.

\section{Risks and Discomforts.}

I understand that my child may experience some pain or discomfort when his/her blood is drawn. There is a slight risk of infection, bruising, and swelling at the site where the blood is drawn.

Initials Date

Page 1 of 2

$02 / 27 / 2002$

\begin{tabular}{r|l} 
& $\begin{array}{l}\text { Division of Family and Consumer Sciences } \\
\text { Phone: 304-293-3402 }\end{array}$ \\
\hline Fax: $304-293-2750$ & PO Box 6124 \\
Morgantown, WV 26506-6124
\end{tabular}

Equal Opportunity/Affirmative Action Institution 
Parental or Guardian Consent and Information Form

Factors Associated with Iron Deficiency among WIC Infants in Rural West Virginia

West Virginia University, Division of Family and Consumer Sciences

\section{Contact Persons.}

For more information about this research I can contact Dr. Fitch at 304-293-3402, ext. 1768. For information regarding my child's rights as a research subject, I may contact the Executive Secretary of the Institutional Review Board at 304-293-7073.

\section{Financial Considerations}

I understand that there will be no cost to me for participation in this study or for any of the supplies that are, used in the study. I understand that I will be compensated $\$ 40.00$ for the time I spend in the interviews with Dr. Fitch or her student. If I complete part, but not all, of the interview session, I understand that I will receive $\$ 10.00$ for my time.

\section{Voluntary Compensation}

If my child is injured as a result of this research, treatment will be available. The investigator, sponsor, West Virginia University, or other associated affiliates will not voluntarily provide compensation for his/her injuries.

\section{Alternatives}

I understand that I have the option not to allow my child to participate in this research study.

\section{Voluntary Participation}

I understand that participation in this study is voluntary. If my child participates, I may withdraw my child from this study at any time. Refusal to participate or withdrawal will involve no penalty or loss of benefits for my child or me, and will not affect my child's participation in WIC services in any way. I have been given the opportunity to ask questions about the research, and I have received answers concerning areas I did not understand. Upon signing this form, I will receive a copy.

\section{Confidentiality}

I understand that any information obtained as a result of my child's participation in this research will be kept as confidential as legally possible. I understand that these research records, just like hospital records, may be subpoenaed by court order or may be inspected by federal regulatory authorities. My name or that of my child or any information from which we might be identified may not be published without my consent.

I willingly consent to my child's participation in this research.

Signature of Parent or Guardian

Signature of Investigator or Investigator's Representative

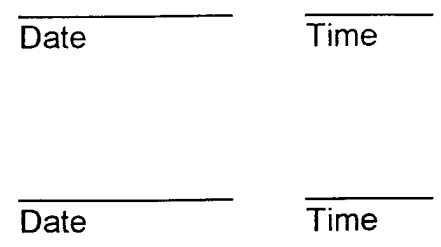




\section{ATTENTION}

Are you interested in learning about your child's iron and lead status? If yes, then join our research study!!

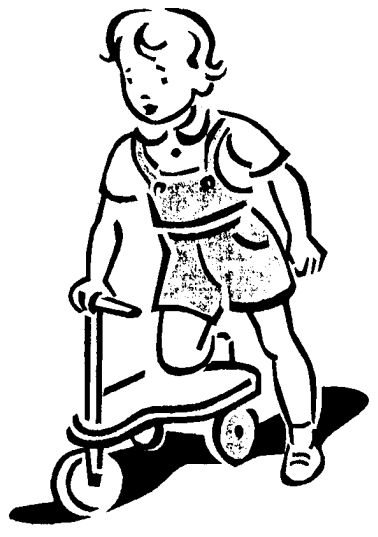

WEST VIRGINIA UNIVERSTTY Institution Review Board for the Protegtion of Human Research Subjects

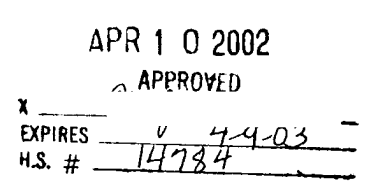

- Your child must be between the ages of 6 months and 2 years.

- Requires about 45 minutes of your time at the WIC clinic and a blood test for iron and lead.

- There is no cost and you will receive a check of $\$ 40.00$ upon completion for each child enrolled.

- Dr. Cindy Fitch, Assistant Professor, Human Nutrition and Foods, West Virginia University, is conducting this study.

- For information, ask the clerk here at the WIC office- or call: (304) 293- 3402

Dr. Cindy Fitch. Ext. 1768

or

Norma \& Kim (Research Assistants) Ext. 1782 
APPENDIX C 


\section{DATA COLLECTION FORM}

Date

Patient Name

Subject Number

Date of Birth

Gender

$\begin{array}{lll}\text { Weight (lbs) } & \text { or } & \text { kg } \\ \text { Length }(\mathrm{cm}) & \text { or } & \mathrm{cm}\end{array}$

Weight for Length

Birth/Delivery Status:

$\begin{array}{lll}\begin{array}{l}\text { Pre-Term } \\ <37 \text { weeks }\end{array} & \text { Full-Term } & \text { Post-Term } \\ & 40 \text { weeks } & >42 \text { weeks }\end{array}$

Length of Gestation

Length at Birth $(\mathrm{cm})$

Weight at Birth (lbs)

MEDICAL HISTORY

History of chronic illness:

Asthma

Disability

Constipation/Vomiting

\section{\% For Age}

$\underline{z \text { score }}$

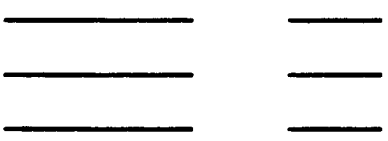

$>42$ weeks

How long ago did the child last have

a) a cough or cold

b) diarrhea

c) ear infection

d) bacterial infection requiring antibiotics

\section{DISEASES}

Diabetes yes no

Kidney Disease yes no

Cancer yes no

Heart Disease yes no

Liver Disease yes no

days
${ }^{\text {days }}{ }^{\text {days }} \_$
days

weeks months weeks _____months weeks ___ months weeks ___ months 
Allergies/Food Intolerances

Medications

Surgeries

Existing Nutritional Deficiencies 
APPENDIX D 


\section{DIET HISTORY}

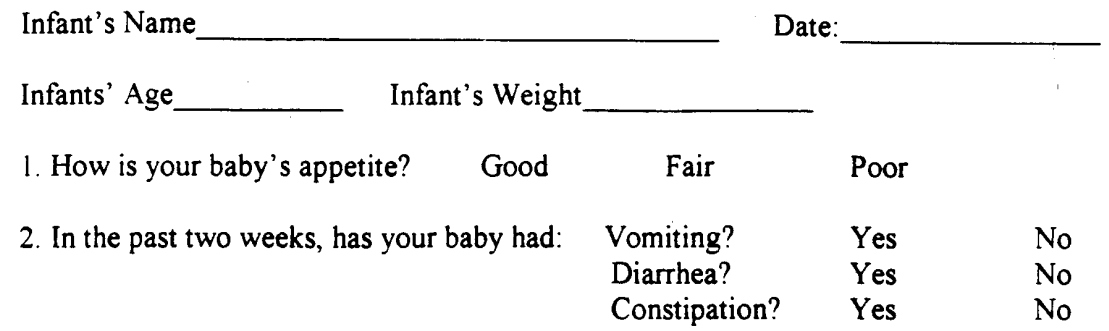

3. Is your baby taking vitamins or minerals (including iron or fluoride)? Yes No

4. What type of water do you use? City Well Spring Cistern Other

5. Do you feed your baby with: A bottle? Yes No

A feeder? Yes No

A cup? $\quad$ Yes No

A spoon? Yes No

6. Do you put cereal or other foods in your baby's bottle? Yes No

7. Is food given to your baby directly from a jar? Yes No

8. How were you feeding you baby when you left the hospital? Breast Bottle Both

9. Are you breastfeeding your baby now? Yes No

10. If you have stopped breastfeeding, how many weeks did you breastfeed?__Weeks Why did you stop?

11. Does the child currently drink cow's milk? Yes No

12. How many glasses of cow's milk does the child drink each day? (Estimat number of 8 ounce glasses of milk per day)

13. Was the mother participating in WIC before or while she was pregnant? Yes No

14. Was the mother taking prenatal vitamins? Yes No 
APPENDIX E 


\section{Hour Recall (Script for In Person Interview)}

1. I'd like you to tell me everything (NAME) had to eat and drink all day yesterday, (DAY), from midnight to midnight. Include everything (he/she) ate and drank at home and away, including meals, snacks, and drinks.

[WHEN RESPONDENT STOPS, ASK: Anything else?]

Now I'm going to ask you for more detail about the foods and beverages you just listed. I will be using this notebook to find the specific questions I need to ask. When you remember anything else (NAME) ate or drank as we go along, please tell me.

When I ask about amounts, you can use these measuring guides: the cups and spoons for volume of foods; the ruler for length, width, and height of foods.

2. About what time did (NAME) begin to (eat/drink) (FOOD ON LIST)? [OR CONFIRM IF RECORDED ON QUICK LIST]

3. Please tell me what you would call this occasion. [BREAKFAST, BRUNCH, LUNCH, DINNER, SUPPER, SNACK, FEEDING, OTHER (SPECIFY) - OR CONFIRM IF RECORDED ON QUICK LIST]

4. Did (NAME) have (NEXT QUICK LIST ITEM) at (TIME) with his/her (OCCASION) or was that at another time? (CONFIRM IF OBVIOUS OR RECORDED ON QUICK LIST. IF SAME TIME AND OCCASION, GO TO STEPS; IF AT ANOTHER TIME, ASK QUESTION 2)

STEPS

\begin{tabular}{|l|l|}
\hline Step 1 & $\begin{array}{l}\text { Transfer quick list food to the food/drink column. Check off food in } \\
\text { quick list as it is transferred. }\end{array}$ \\
\hline Step 2 & $\begin{array}{l}\text { Go to column } 4 \text { for food probes. Be sure to request food labels if } \\
\text { respondent cannot answer probes. }\end{array}$ \\
\hline Step 3 & Go to column 5 for amount question \\
\hline Step 4 & Return to question 2 for next food recorded on quick list. \\
\hline
\end{tabular}

\section{REVIEW}

5. Now let's see if I have everything. I'd like you to try to remember anything else (NAME) ate or drank yesterday that you haven't already told me about, including anything (NAME) ate or drank while waiting to eat.

6. Did (NAME) have anything to eat or drink between midnight yesterday and (NAME'S) (TIME) (FIRST OCCASION)?

7. Now at (TIME) for (THIS OCCASION) (NAME) had (FOODS), did (NAME) have anything else? 
8. Did (NAME) have anything to eat or drink between (NAME'S) (TIME) (THIS OCCASION) and (TIME) when (NAME) had (NEXT OCCASION)?

9. Repeat 7 and 8 for each occasion except last occasion. For last occasion go to 10 .

10. Now at (TIME) for (LAST OCCASION) (NAME) had (FOODS), did (he/she) have anything else?

11. Did (NAME) have anything to eat or drink after (NAME'S) (TIME) (LAST OCCASION) but before midnight last night?

12. Was the amount of food that (NAME) ate yesterday about usual, less than usual, or more than usual?

13. What is the main reason the amount (NAME) ate yesterday was (less/more) than usual?

14. Now l'd like you to think about all of the plain drinking water that (NAME) had yesterday, regardless of where (he/she) drank it. By plain drinking water, I mean tap water or any bottled water that is not carbonated, with anything added to it.

15. How many fluid ounces of plain drinking water did (NAME) drink yesterday?

16. How much of this plain drinking water came from your home? Would you say all, most, some, or none?

17. What was the main source of plain drinking water that did not come from your home? Was it tap water, water from a drinking fountain, bottled water, or something else?

18. Is (NAME) on any type of special diet for a health-related reason?

19. How often, if at all does (NAME) take any vitamin or mineral supplement? Would you say every day or almost every day, every so often, or not at all?

20. What types of supplements does (NAME) usually take - a multivitamin; a multivitamin with iron or other minerals; combination of specific vitamins? (list all that apply).

Interviewer Observations

Do not read these questions to the respondent.

1. Who was the main respondent for this interview? (Mother, father, sister, brother, grandparent, aunt, uncle, someone else)

2. Who else helped in responding for this interview? 
3. Did you or the respondent have difficulty with this intake interview?

4. What was the reason for this difficulty?

5. Is data retrieval necessary for daycare/baby-sitter or other caretaker? If yes, record information for follow-up phone call. 
APPENDIX F 
ID Number

Individual Intake Forms

\begin{tabular}{|c|c|c|c|}
\hline $\begin{array}{c}\text { Column1 } \\
\text { Quick List of Food Items }\end{array}$ & $\sqrt{ }$ & $\begin{array}{c}\text { Column } 2 \\
\text { Time }\end{array}$ & $\begin{array}{l}\text { Column } 3 \\
\text { Occasion }\end{array}$ \\
\hline A. & & $\begin{array}{l}\mathrm{am} \\
\mathrm{pm}\end{array}$ & \\
\hline B. & & $\begin{array}{l}\mathrm{am} \\
\mathrm{pm}\end{array}$ & \\
\hline C. & & $\begin{array}{l}\mathrm{am} \\
\mathrm{pm}\end{array}$ & \\
\hline D. & & $\begin{array}{l}\mathrm{am} \\
\mathrm{pm}\end{array}$ & \\
\hline $\mathrm{E}$. & & $\begin{array}{l}\mathrm{am} \\
\mathrm{pm}\end{array}$ & \\
\hline $\mathrm{F}$. & & $\begin{array}{l}\mathrm{am} \\
\mathrm{pm}\end{array}$ & \\
\hline G. & & $\begin{array}{l}\mathrm{am} \\
\mathrm{pm}\end{array}$ & \\
\hline $\mathrm{H}$. & & $\begin{array}{l}\mathrm{am} \\
\mathrm{pm}\end{array}$ & \\
\hline $\mathrm{I}$. & & $\begin{array}{l}\mathrm{am} \\
\mathrm{pm}\end{array}$ & \\
\hline $\mathrm{J}$. & & $\begin{array}{l}\mathrm{am} \\
\mathrm{pm}\end{array}$ & \\
\hline $\mathrm{K}$. & & $\begin{array}{l}\mathrm{am} \\
\mathrm{pm}\end{array}$ & \\
\hline L. & & $\begin{array}{l}\mathrm{am} \\
\mathrm{pm}\end{array}$ & \\
\hline M. & & $\begin{array}{l}\mathrm{am} \\
\mathrm{pm}\end{array}$ & \\
\hline $\mathrm{N}$ & & $\begin{array}{l}\mathrm{am} \\
\mathrm{pm}\end{array}$ & \\
\hline $\mathrm{O}$. & & $\begin{array}{l}\mathrm{am} \\
\mathrm{pm}\end{array}$ & \\
\hline P. & & $\begin{array}{l}\mathrm{am} \\
\mathrm{pm}\end{array}$ & \\
\hline Q. & & $\begin{array}{l}\mathrm{am} \\
\mathrm{pm}\end{array}$ & \\
\hline R. & & $\begin{array}{l}\mathrm{am} \\
\mathrm{pm}\end{array}$ & \\
\hline S. & & $\begin{array}{l}\mathrm{am} \\
\mathrm{pm}\end{array}$ & \\
\hline $\mathrm{T}$. & & am & \\
\hline
\end{tabular}


ID Number

Page 2

\begin{tabular}{|c|c|c|}
\hline $\begin{array}{c}\text { Food/Drink with } \\
\text { Additions }\end{array}$ & $\begin{array}{c}\text { Column } 4 \\
\text { Description of Food/Drink } \\
\text { and Ingredient Amounts }\end{array}$ & $\begin{array}{c}\text { Column } 5 \\
\text { How much of this } \\
\text { (FOOD) did (NAME) } \\
\text { actually (eat/drink)? }\end{array}$ \\
\hline 1. & & \\
\hline 2. & & \\
\hline 3. & & \\
\hline 4. & & \\
\hline 5. & & \\
\hline 6. & & \\
\hline 7. & & \\
\hline 8. & & \\
\hline 9. & & \\
\hline 10. & & \\
\hline 11. & & \\
\hline 12. & & \\
\hline 13. & & \\
\hline 14. & & \\
\hline 15. & & \\
\hline 16. & & \\
\hline 17. & & \\
\hline 18. & & \\
\hline 19. & & \\
\hline 20. & & \\
\hline
\end{tabular}


12. Amount of food Usual Less More

13. Reason

15. Ounces of plain drinking water

16. Amount from home

17. Source of water outside of home

18. Special formula or diet?

19. Vitamin or minerals Daily Occasionally Not at all

20. Types of supplements (brand)

Interviewer Observations

1. Main respondent

2. Additional respondent

3. Any difficulty

4. Reason

5. Information for follow-up phone call 
APPENDIX G 


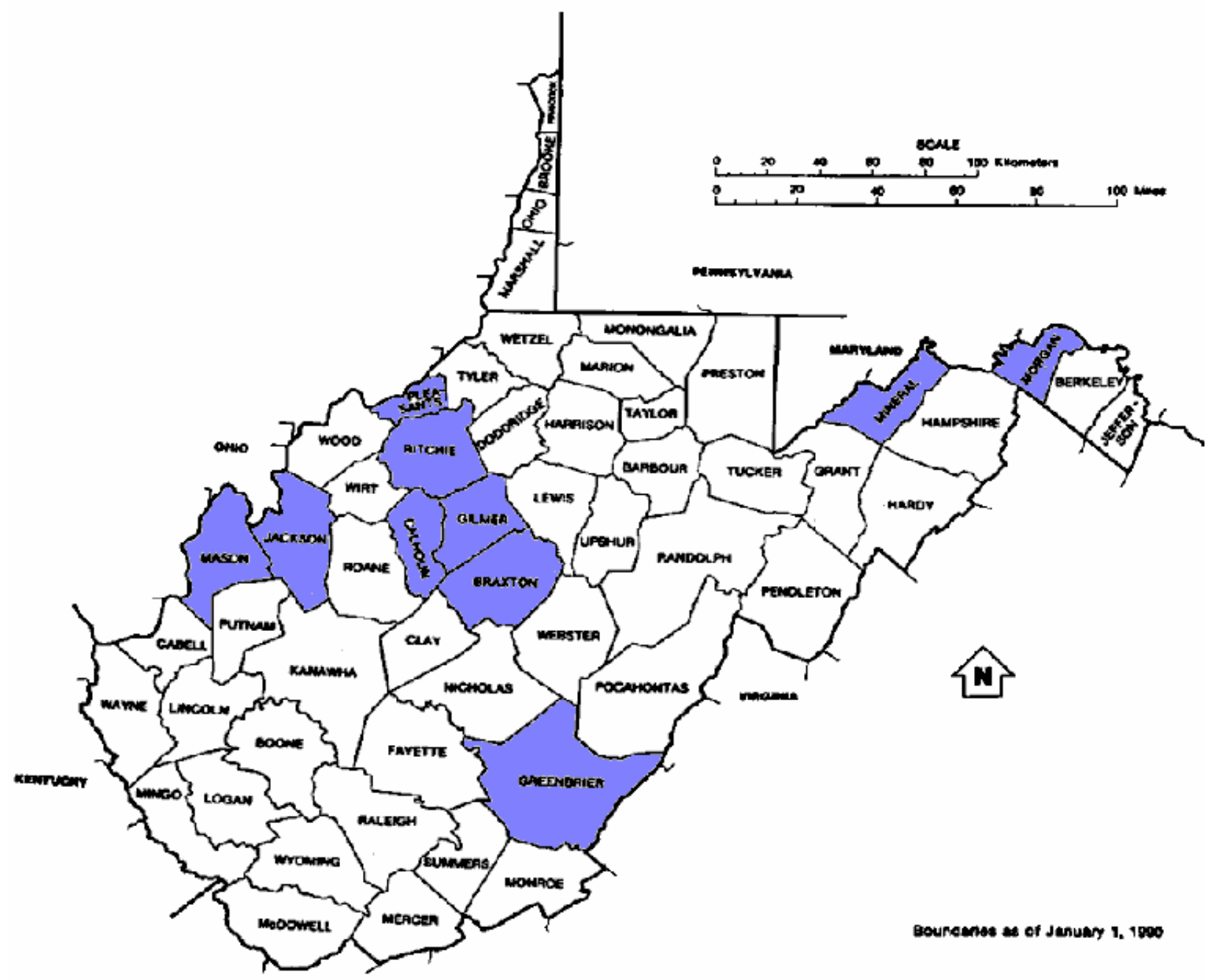

